\title{
PENGARUH KEPEMIMPINAN DAN PENGAWASAN TERHADAP KINERJA PEGAWAI DI KANTOR KECAMATAN TUGUMULYO KABUPATEN MUSI RAWAS
}

\author{
Irma Idayati ${ }^{1}$, Hardi Mulyono ${ }^{2}$ \\ Universitas Bina Insan Kota lubuklinggau ${ }^{1,2}$ \\ $\underline{\text { Irmaidayati719@gmail.com }}{ }^{1}$
}

\begin{abstract}
ABSTRAK
Penelitian ini bertujuan untuk mengetahui pengaruh Kepemimpinan dan Pengawasan terhadap Kinerja Karyawan di Kantor Kecamatan Tugumulyo di Kabupaten Musi Rawas. Metode penelitian yang digunakan dalam penelitian ini adalah penelitian kuantitatif. Hasil penelitian menggunakan regresi berganda hasil koefisien determinasi (R2) sebesar 47,7\% artinya, kepemimpinan dan pengawasan memiliki efek 47,7\%, sedangkan 52,3\% dipengaruhi oleh variabel lain. Untuk hasil uji $\mathrm{F}$ dapat diketahui nilai Fhitung $=12,300>\mathrm{F}$ tabel $=3,32$. Artinya, nilai Fcount lebih besar dari nilai Fable. Simpulan, ada pengaruh yang signifikan antara Kepemimpinan dan Pengawasan Kinerja Karyawan di Kantor Distrik Tugumulyo di Kantor Musi Rawas.
\end{abstract}

Kata kunci: Kepemimpinan, Kinerja, Pengawasan

\begin{abstract}
This study aims to learn about Leadership and Supervision of Employee Performance at the Tugumulyo District Office in Musi Rawas Regency. The research method used in this research is quantitative research. The results of the study using multiple regression results the coefficient of determination (R2) of $47.7 \%$ means, leadership and supervision have an effect of $47.7 \%$, while $52.3 \%$ is needed by other variables. Fcount $=12,300>F$ table $=3.32$. Value, the Fcount value is greater than the Fable value. Conclusion, there is a significant leadership between Leadership and Supervision of Employee Performance in the Tugumulyo District Office in the Musi Rawas Office.
\end{abstract}

Keywords: Leadership, Performance, Supervision

\section{PENDAHULUAN}

Manajemen sumber daya manusia merupakan salah satu bagian terpenting suatu organisasi dalam menjalankan aktivitasnya untuk mencapai tujuan yang telah direncanakan.Setiap organisasi berusaha untuk mencapai tujuan tersebut semaksimal mungkin.Dan tingkat keberhasilan pencapaian organisasi itu sendiri ditentukan dari seberapa maksimal kinerja yang dicapai para pegawainya. Di Indonesia, masalah kinerja merupakan sebuah tugas bagi pemerintah yang perlu diperbaiki. Kepuasan masyarakat terhadap pelayanan publik masih rendah, hal tersebut dipengaruhi oleh berbagai macam faktor, salah satunya adalah faktor kinerja pegawai dalam pelayanan publik yang masih 
kurang. Sebagaimana diketahui bersama, banyak faktor yang menyebabkan rendahnya kinerja pegawai negeri sipil, salah satunya dikarenakan lemahnya sistem kepemimpinan dan pengawasan dari pimpinan maupun dari pengawas setempat (Irham 2016; Mirsa et al., 2017).

Setiap organisasi dalam menjalankan tugasnya senantiasa memerhatikan dan menerapkan kepemimpinan yang baik, hal ini mengingat bahwa kepemimpinan merupakan kemampuan untuk mempengaruhi orang lain, bawahan atau kelompok, kemampuan mengarahkan tingkah laku bawahan atau kelompok, memiliki kemampuan atau keahlian khusus dalam bidang yang diinginkan oleh kelompoknya, untuk mencapai tujuan organisasi atau kelompok (Andri, Endang, 2015). Dan jika pimpinan telah menerapkan kepemimpinan dengan baik, maka pegawai akan dapat mencapai kinerja yang maksimal (Mulyadi, Safitri 2015).

Selain faktor kepemimpinan, pengawasan dari aparatur pengawas setempat juga memengaruhi pencapaian kinerja dari masing-masing pegawai. Hal ini mengingat bahwa pengawasan tidak hanya melihat sesuatu dengan seksama dan melaporkan hasil kegiatan mengawasi, tetapi juga mengandung arti memperbaiki dan meluruskannya sehingga mencapai tujuan yang sesuai dengan apa yang telah direncanakan (Andri, Endang, 2015). Semakin baik tingkat pengawasan di suatu organisasi, maka tingkat kedisiplinan pegawai akan meningkat dan pada akhirnya kinerja pegawai akan maksimal sesuai dengan tujuan yang telah ditetapkan.

Kepemimpinan dan Pengawasan yang dilakukan oleh pimpinan kepada bawahan akan dapat mendorong bawahan melakukan pekerjaan dengan disiplin kerja yang tinggi. Kepemimpinan dan pengawasan terhadap pegawai yang berjalan dengan baik juga dapat mengurangi tingkat kesalahan sehingga kinerja pegawai akan lebih maksimal. Titik berat kepemimpinan dan pengawasan sesuangguhnya terdapat pada manusianya, karena manusia itulah yang melakukan kegiatan-kegiatan dalam badan usaha atau instansi pemerintah yang bersangkutan (Irham, 2018).

Kantor Camat mempunyai tugas pokok yaitu melaksanakan kewenangan pemerintah yang dilimpahkan oleh Bupati untuk menangani sebagian urusan otonomi daerah dan menyelenggarakan tugas umum pemerintah. Dilihat dari kedudukannya, kantor Camat merupakan tempat yang sangat rentan terhadap penyalahgunaan fungsinya. Oleh karena itu, untuk menunjang pelaksanaan kegiatan operasional, 
perluditetapkan tindakan kepemimpinan dan pengawasan yang baik oleh seorang pimpinan terhadap bawahannya.

Kantor Kecamatan Tugumulyo merupakan salah satu instansi yang berada di bawah naungan pemerintah Kabupaten Musi Rawas, dengan visi "Terwujudnya Pelayanan Publik Yang Baik di Kecamatan Tugumulyo Menuju Musi Rawas SEMPURNA" dan misinya yaitu: peningkatan kualitas aparatur pemerintah Kecamatan dan Desa/Kelurahan, peningkatan keberdayaan dan partisipasi masyarakat dalam proses pembangunan, pembangunan masyarakat berwawasan kebangsaan, selalu berupaya memberikan kinerja yang terbaik karena mengingat Kantor Kecamatan Tugumulyo merupakan ujung tombak pelayanan masyarakat Tugumulyo secara langsung. Untuk itu, pimpinan Kantor Kecamatan Tugumulyo sangat berupaya untuk memberikan sikap kepemimpinan dan pengawasan yang baik kepada para pegawainya.

Namun demikian, berdasarkan pengamatan awal yang berkaitan dengan kinerja yaitu hasil kinerja pegawai yang belum maksimal dan hasil kinerja pegawai masih belum sesuai dengan rencana yang telah ditetapkan.Sementara itu, pengamatan awal yang berkaitan dengan kepemimpinan yaitu, selama ini masih ada beberapa pegawai yang menyepelekan pimpinan, masih adanya pegawai yang memanfaatkan sikap toleransi pimpinan dan kurangnya ketegasan pimpinan dalam menghadapi bawahan.Sedangkan permasalahan yang berkaitan dengan pengawasan, yaitu masih lemahnya pengawasan terhadap pegawai sehingga masih adanya pegawai yang kurang disiplin terutama saat masuk jam kerja dan masih adanya pegawai yang harus ditegur dulu baru bekerja.

\section{KAJIAN TEORI}

\section{Kepemimpinan}

\section{Pengertian Kepemimpinan}

Menurut Wibowo (2016) kinerja berasal dari pengertian performance. Ada pula yang memberikan pengertian performance sebagai hasil kerja atau prestasi kerja. Namun, sebenarnya kinerja mempunyai makna yang lebih luas, bukan hanya hasil kerja, tetapi termasuk bagaimana proses pekerjaan berlangsung. 
Menurut Erni, Donni (2018) yang dimaksud dengan kinerja merupakan perwujudan atas pekerjaan yang telah dihasilkan atau diemban pegawai.

Sedangkan menurut Fahmi (2018) kinerja adalah hasil yang diperoleh suatu organisasi baik organisasi tersebut bersifat profit oriented atau non profit oriented yang dihasilkan selama satu periode waktu.

\section{Indikator Kepemimpinan}

Menurut Brantas dalam Fahmi (2018) kepemimpinan tidak terlepas dari nilainilai yang dimiliki oleh pemimpin seperti diungkapkan oleh Guth dan Taguiri (dalam Salusu, 2008) adalah:

Teoritis, yaitu nilai-nilai yang berhubungan dengan usaha mencari kebenaran dan mencari pembenaran secara rasional. Ekonomis, yaitu yang tertarik pada aspekaspek kehidupan yang penuh keindahan, menikmati setiap peristiwa untuk kepentingan sendiri. Sosial, menaruh belas kasihan pada orang lain, simpati, tidak mementingkan diri sendiri. Politis, berorientasi pada kekuasaan dan melihat kompetisi sebagai faktor yang sangat vital dalam kehidupannya. Religius, selalu menghubungkan setiap aktivitas dengan kekuasaan sang pencipta.

\section{Manfaat Kepemimpinan}

Menurut Sondang P.Siagian dalam Fahmi (2018) fungsi kepemimpinan terdiri dari: Pimpinan sebagai penentu arah, Pimpinan sebagai wakil dan juru bicara organisasi, Pimpinan sebagai komunikator yang aktif, pimpinan sebagai mediator dan sebagai integrator.

\section{Pengawasan}

\section{Pengertian Pengawasan}

Menurut Fahmi (2016) pengawasan adalah suatu bentuk pengamatan yang umumnya dilakukan secara menyeluruh, dengan jalan mengadakan perbandingan antara yang dikonstatir dan yang harus dilakukan.

Menurut Busro (2018) pengawasan dapat dipahami sebagai suatu usaha untuk melakukan kendali terhadap karyawan dalam melakukan pekerjaannya yang dilakukan oleh pimpinan perusahaan untuk mengukur apakah pekerjaan karyawan tersebut sudah 
sesuai atau belum dengan rencana yang telah ditetapkan perusahaan, dan apabila terjadi kesalahan dapat diperbaiki dan dicari solusi terbaik agar tidak terulang di kemudian hari.

Sedangkan menurut Manullang (2015) pengawasan dapat diartikan sebagai suatu proses untuk menerapkan pekerjaan apa yang sudah dilaksanakan, menilainya, dan bila perlu mengoreksi dengan maksud supaya pelaksanaan pekerjaan sesuai dengan rencana semula.

\section{Indikator Pengawasan}

Menurut Gavinov (2016) indikator pengawasan adalah sebagai berikut: Standar hasil yang direncanakan untuk dicapai. Anggaran, merupakan suatu rencana kerja yang dinyatakan dengan uang. Data statistik, analisis statistic dari berbagai segi operasional suatu organisasi merupakan alat pengawasan yang sangat penting bagi manajemen. Laporan dapat berbentuk lisan maupun tulisan.Auditing, merupakan usaha verifikasi yang sistematis dan ditunjukkan pada berbagai segi operasional dan organisasi. Observasi langsung, dengan melakukan observasi langsung, manajer akan memperoleh masukan yang sangat penting baginya dalam usaha menentukan tindakan korektif apa yang perlu diambilnya.

\section{Manfaat Pengawasan}

Menurut Busro (2018) manfaat dari pengawasan adalah untuk mengetahui apakah perencanaan yang telah ditetapkan sejalan dengan tindakan yang telah diambil, sehingga tidak terdapat penyelewengan yang dapat merugikan perusahaan.

\section{Kinerja}

\section{Pengertian Kinerja}

Menurut Wibowo (2016) kinerja berasal dari pengertian performance. Ada pula yang memberikan pengertian performance sebagai hasil kerja atau prestasi kerja. Namun, sebenarnya kinerja mempunyai makna yang lebih luas, bukan hanya hasil kerja, tetapi termasuk bagaimana proses pekerjaan berlangsung.

Menurut Erni, Donni (2018) yang dimaksud dengan kinerja merupakan perwujudan atas pekerjaan yang telah dihasilkan atau diemban pegawai. 
Sedangkan menurut Fahmi (2018) kinerja adalah hasil yang diperoleh suatu organisasi baik organisasi tersebut bersifat profit oriented atau non profit oriented yang dihasilkan selama satu periode waktu.

\section{Indikator Kinerja}

Menurut Harun (2018) indikator kinerja yaitu sebagai berikut :

Kualitas kerja (Quality of work), adalah kualitas kerja yang dicapai berdasarkan syarat-syarat kesesuaian dan kesiapannya yang tinggi pada gilirannya akan melahirkan penghargaan dan kemajuan serta perkembangan organisasi melalui peningkatan pengetahuan dan keterampilan secara sistematis sesuai tuntutan ilmu pengetahuan dan teknologi yang semakin berkembang pesat.

Ketetapan waktu (Pomptness), yaitu berkaitan dengan sesuai atau tidaknya waktu penyelesaian pekerjaan dengan target waktu yang direncanakan .

Inisiatif (Initiative), yaitu mempunyai kesadaran diri untuk melakukan sesuatu dalam melaksanakan tugas-tugas dan tanggung jawab.

Kemampuan (Capability), diantara beberapa faktor yang memengaruhi kinerja seseorang, ternyata yang dapat diintervensi atau diterapi melalui pendidikan dan pelatihan adalah faktor kemampuan yang dapat dikembangkan.

Komunikasi (Communication), merupakan interaksi yang dilakukan oleh atasan kepada bawahan untuk mengemukakan saran dan pendapatnya dalam memecahkan masalah yang dihadapi.

\section{Manfaat Kinerja}

Menurut Wibowo (2016) manfaat kinerja adalah sebagai berikut:

Manfaat kinerja bagi organisasi, antara lain: menyesuaikan tujuan organisasi dengan tujuan tim, individu, memperbaiki kinerja, memotivasi kinerja, meningkatkan komitmen, mendukung nilai-nilai inti, memperbaiki proses pelatihan dan pengembangan, meningkatkan dasar keterampilan, mengusahakan perbaikan, dan perkembangan berkelanjutan, mengusahakan basis perencanaan karier, membantu menahan pekerja untuk tidak pindah, mendukung inisiatif kualitas total dan pelayanan, dan mendukung program perubahan budaya.

Manfaat kinerja bagi manajer, antara lain: mengusahakan klarifikasi kinerja dan perilaku, menawarkan peluang menggunakan waktu secara berkualitas, memperbaiki kinerja tim dan individu, mengusahakan penghargaan non finansial bagi staf. 
Mengusahakan dasar untuk membantu pegawai yang kinerjanya rendah, digunakan untuk pengembangan individu, mendukung kepemimpinan atasan, proses motivasi dan pengembangan tim, mengusahakan kerangka kerja untuk meninjau kembali kinerja dan tingkat kompetensi.

Manfaat kinerja bagi individu, antara lain: memperjelas peran dan tujuan, mendorong dan mendukung untuk tampil baik, membantu mengembangkan kemampuan dan kinerja, peluang menggunakan waktu secara berkualitas, dasar objektivitas dan kejujuran untuk mengukur kinerja, dan memformulasi tujuan dan rencana perbaikan cara bekerja dikelola dan dijalankan.

\section{METODE PENELITIAN}

\section{Jenis dan Rancangan Penelitian}

Jenis penelitian yang digunakan dalam penelitian ini penelitian kuantitatif. Rancangan penelitian dimulai dari melakukan survei atau mengunjungi Kantor Kecamatan Tugumulyo Kabupaten Musi Rawas dengan tujuan untuk mengetahui lokasi dan melakukan pendekatan. Kemudian peneliti merumuskan masalah dan menentukan tujuan penelitian. Kemudian peneliti menentukan judul yang sesuai dengan permasalahan yang terjadi di lokasi penelitian, yaitu Pengaruh Kepemimpinan dan Pengawasan terhadap Kinerja Pegawai di Kantor Kecamatan Tugumulyo Kabupaten Musi Rawas. Menentukan konsep dan menggali kepustakaan tentang kepemimpinan dan pengawasan serta kinerja. Setelah itu melakukan pengambilan sampel dan observasi, pembuatan kuesioner, wawancara, pengolahan data dan analisis data.

\section{Tempat dan Waktu Penelitian}

\section{Tempat Penelitian}

Tempat penelitian ini adalah Kantor Kecamatan Tugumulyo Kabupaten Musi Rawas. Jalan Jenderal Sudirman No. 162, Kelurahan B. Srikaton, Kecamatan Tugumulyo, kabupaten Musi Rawas. Kode Pos 31662. Telpon (0733) 371101.

\section{Waktu Penelitian}

Waktu penelitian ini akan dilaksanakan selama 7 bulan, yakni dimulai dari bulan Maret s/d bulan September 2019. 


\section{Populasi dan Sampel}

Populasi dalam penelitian ini adalah seluruh pegawai di Kantor Kecamatan Tugumulyo Kabupaten Musi Rawas yang berjumlah 31 orang. Sampel dalam penelitian ini adalah sampel jenuh.Sampel jenuh adalah teknik penentuan sampel bila semua anggota populasi digunakan sebagai sampel. Sampel dalam penelitian ini yaitu seluruh pegawai berjumlah 30 orang, kecuali Camat tidak diteliti karena dianggap sebagai subjek penelitian.

\section{Sumber Data}

Data primer, adalah sumber data yang langsung memberikan data kepada pengumpul data. Dalam penelitian ini data yang diperoleh atau dikumpulkan langsung di lapangan yaitu dengan wawancara atau menyebarkan kuesioner untuk diisi oleh responden.

Data sekunder, merupakan sumber yang tidak langsung memberikan data kepada pengumpul data. Dalam penelitian ini, sumber data yang dikumpulkan adalah dokumentasi dan kepustakaan yaitu buku-buku dan beberapa literatur yang berkaitan dengan masalah yang digunakan dalam penelitian ini. Misalnya struktur organisasi, visi dan misi, jumlah pegawai dan lain-lain.

\section{Teknik Pengumpulan Data}

Teknik pengumpulan data ini mendasarkan diri pada laporan tentang diri sendiri atau self-report, atau setidak-tidaknya pada pengetahuan dan atau keyakinan pribadi.

Kuesioner merupakan suatu teknik pengumpulan data yang dilakukan dengan cara memberi seperangkat pertanyaan atau pernyataan tertulis kepada responden untuk dijawabnya.

Observasi, Teknik pengumpulan data dengan observasi digunakan bila penelitian berkenaan dengan perilaku manusia, proses kerja, gejala-gejala alam dan bila responden yang diamati tidak terlalu besar. 
HASIL PENELITIAN

Karakteristik Responden

Tabel 1. Karakteristik Responden Berdasarkan Jenis Kelamin

\begin{tabular}{ccc}
\hline Jenis Kelamin & Frequency & Percent \\
\hline Laki-laki & 15 & 50,0 \\
Perempuan & 15 & 50,0 \\
Total & 30 & 100,0 \\
\hline
\end{tabular}

Pada tabel 1 menunjukkan bahwa jumlah responden laki-laki dan perempuan sama banyak yaitu masing-masing 15 orang (50\%) laki-laki dan perempuan.

\section{Hasil Uji Regresi Linear}

Tabel 2. Hasil Uji Regresi Berganda

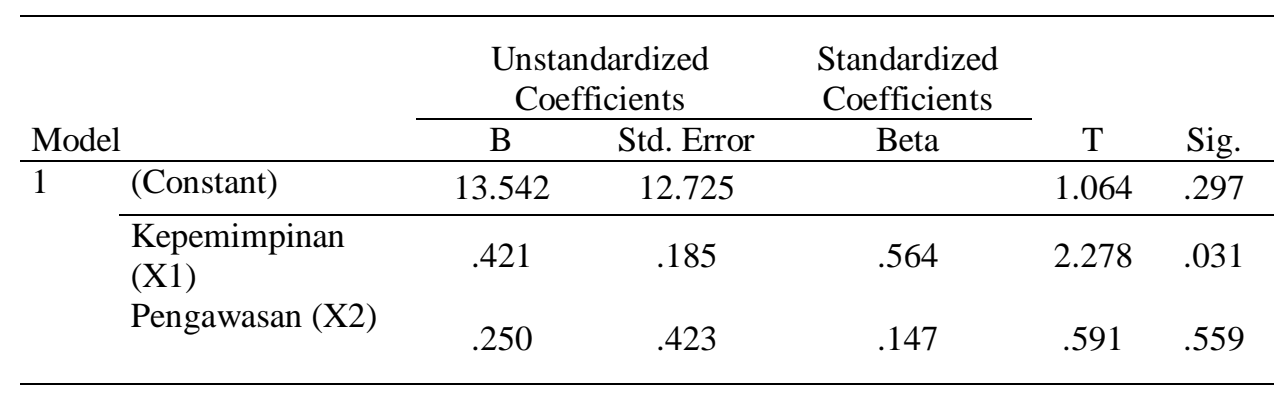

Berdasarkan hasil perhitungan regresi, maka diperoleh nilai $a=13,542$, nilai $b_{1}$ $=0,421$, nilai $b_{2}=0,250$. Kemudian hasil perhitungan tersebtu dimasukkan ke dalam persamaan regresi linear berganda sebagai berikut:

$$
Y=13,542+0,42 X_{1}+0,250 X_{2}
$$

Arti persamaan tersebut adalah bahwa nilai konstanta sebesar a $=13,542$. Ini berarti bahwa jika tidak ada variabel Kepemimpinan dan Pegawasan, maka variabel Kinerja Pegawai sebesar 13,542 satuan. Sedangkan nilai koefisien regresi Kepemimpinan sebesar $b_{1}=0,421$, artinya setiap terjadi peningkatan satu satuan variabel Kepemimpinan, maka akan meningkatkan variabel Kinerja Pegawai sebesar 0,421 satuan. Dan nilai koefisien regresi Pengawasan sebesar $b_{2}=0,250$, artinya setiap terjadi peningkatan satu satuan variabel Pengawasan, maka akan meningkatkan variabel Kinerja Pegawai sebesar 0,250 satuan. 


\section{Uji F}

Uji F digunakan untuk mengetahui pengaruh secara simultan antara variabel Kepemimpinan $\left(\mathrm{X}_{1}\right)$ dan variabel Pengawasan $\left(\mathrm{X}_{2}\right)$ terhadap variabel Kinerja $(\mathrm{Y})$. Berikut adalah hasil uji F untuk pengaruh Kepemimpinan dan Pengawasan terhadap Kinerja Pegawai di Kantor Kecamatan Tugumulyo Kabupaten Musi Rawas:

Tabel 3 Hasil Uji F

\begin{tabular}{llccccc}
\hline Model & Sum of Squares & df & Mean Square & F & Sig. \\
\hline 1 & Regression & 533.327 & 2 & 266.663 & 12.300 & $.000^{\mathrm{b}}$ \\
& Residual & 585.340 & 27 & 21.679 & & \\
& Total & 1118.667 & 29 & & & \\
\hline
\end{tabular}

Dari tabel Anova di atas, terlihat bahwa nilai $f_{\text {hitung }}$ adalah sebesar 12,300, sedangkan untuk nilai $\mathrm{f}_{\text {tabel }}$ dengan tingkat signifikan 0,000 serta $\alpha=5 \%$ serta pembilang $\mathrm{k}=2$ adalah sebesar 3,32. Artinya terdapat pengaruh yang signifikan antara Kepemimpinan dan Pengawasan terhadap Kinerja Pegawai.

\section{PEMBAHASAN}

Hasil penelitian menunjukkan bahwa nilai konstanta sebesar $a=13,542$. Ini berarti bahwa jika tidak ada variabel Kepemimpinan dan Pegawasan, maka variabel Kinerja Pegawai sebesar 13,542 satuan. Sedangkan nilai koefisien regresi Kepemimpinan sebesar $b_{1}=0,421$, artinya setiap terjadi peningkatan satu satuan variabel Kepemimpinan, maka akan meningkatkan variabel Kinerja Pegawai sebesar 0,421 satuan. Dan nilai koefisien regresi Pengawasan sebesar $b_{2}=0,250$, artinya setiap terjadi peningkatan satu satuan variabel Pengawasan, maka akan meningkatkan variabel Kinerja Pegawai sebesar 0,250 satuan.

Dari tabel Anova di atas, terlihat bahwa nilai $f_{\text {hitung }}$ adalah sebesar 12,300, sedangkan untuk nilai $\mathrm{f}_{\text {tabel }}$ dengan tingkat signifikan 0,000 serta $\alpha=5 \%$ serta pembilang $\mathrm{k}=2$ adalah sebesar 3,32. Jika $\mathrm{f}_{\text {hitung }}>\mathrm{f}_{\text {tabel }}$ maka. Artinya terdapat pengaruh yang signifikan antara Kepemimpinan dan Pengawasan terhadap Kinerja Pegawai.

Manajemen sumber daya manusia merupakan salah satu bagian terpenting suatu organisasi dalam menjalankan aktivitasnya untuk mencapai tujuan yang telah direncanakan.Setiap organisasi berusaha untuk mencapai tujuan tersebut semaksimal mungkin.Dan tingkat keberhasilan pencapaian organisasi itu sendiri ditentukan dari seberapa maksimal kinerja yang dicapai para pegawainya. Di Indonesia, masalah kinerja 
merupakan sebuah tugas bagi pemerintah yang perlu diperbaiki. Kepuasan masyarakat terhadap pelayanan publik masih rendah, hal tersebut dipengaruhi oleh berbagai macam faktor, salah satunya adalah faktor kinerja pegawai dalam pelayanan publik yang masih kurang.Sebagaimana diketahui bersama, banyak faktor yang menyebabkan rendahnya kinerja pegawai negeri sipil, salah satunya dikarenakan lemahnya sistem kepemimpinan dan pengawasan dari pimpinan maupun dari pengawas setempat.

Setiap organisasi dalam menjalankan tugasnya senantiasa memerhatikan dan menerapkan kepemimpinan yang baik, hal ini mengingat bahwa kepemimpinan merupakan kemampuan untuk mempengaruhi orang lain, bawahan atau kelompok, kemampuan mengarahkan tingkah laku bawahan atau kelompok, memiliki kemampuan atau keahlian khusus dalam bidang yang diinginkan oleh kelompoknya, untuk mencapai tujuan organisasi atau kelompok (Andri, Endang, 2015). Dan jika pimpinan telah menerapkan kepemimpinan dengan baik, maka pegawai akan dapat mencapai kinerja yang maksimal.

Selain faktor kepemimpinan, pengawasan dari aparatur pengawas setempat juga memengaruhi pencapaian kinerja dari masing-masing pegawai. Hal ini mengingat bahwa pengawasan tidak hanya melihat sesuatu dengan seksama dan melaporkan hasil kegiatan mengawasi, tetapi juga mengandung arti memperbaiki dan meluruskannya sehingga mencapai tujuan yang sesuai dengan apa yang telah direncanakan (Andri, Endang, 2015). Semakin baik tingkat pengawasan di suatu organisasi, maka tingkat kedisiplinan pegawai akan meningkat dan pada akhirnya kinerja pegawai akan maksimal sesuai dengan tujuan yang telah ditetapkan.

\section{SIMPULAN}

1. Kepemimpinan mempunyai pengaruh yang signifikan terhadap kinerja pegawai di Kantor Kecamatan Tugumulyo Kabupaten Musi Rawas.

2. Pengawasan mempunyai pengaruh yang signifikan terhadap kinerja pegawai di Kantor Kecamatan Tugumulyo Kabupaten Musi Rawas.

3. Kepemimpinan dan Pengawasan mempunyai pengaruh yang signifikan terhadap kinerja pegawai di Kantor Kecamatan Tugumulyo Kabupaten Musi Rawas. 
DAFTAR PUSTAKA

Andri, F., \& Endang, T. S. (2015). Pengantar Manajemen (3 in 1). Cetakan Pertama. Yogyakarta: Mediatera

Busro, B. (2018). Teori-teori Manajemen Sumber Daya Manusia. Cetakan Pertama. Jakarta: Prenada Media Group

Erni, T. S., \& Donni, P. (2018). Kepemimpinan \& Perilaku Organisasi. Cetakan Pertama. Bandung: PT. Refika Aditama

Irham, F. (2016). Manajemen Sumber Daya Manusia (Teori dan Aplikasi). Cetakan Pertama. Bandung: Alfabeta

Irham, F. (2016). Pengantar Manajemen Sumber Daya Manusia (Konsep \& Kinerja). Cetakan Pertama. Jakarta: Mitra Wacana Media

Irham, F. (2018). Pengantar Ilmu Kepemimpinan. Cetakan Pertama. Depok: PT Raja Grafindo Persada

Gavinov, I. T. (2016). Manajemen Perkantoran. Yogyakarta: Parama Publishing

Harun, S. (2018). Kinerja Karyawan (Tinjauan dari Dimensi Gaya Kepemimpinan, Budaya Organisasi dan Komitmen Organisasi). Cetakan Pertama. Sidoarjo: Indomedia Pustaka

Manullang, M. (2015). Dasar - Dasar Manajemen. Cetakan ke-23. Yogyakarta: Gadjah Mada University Press

Mirsa, L., Bernhard, T., \& Walangitan, M. D. (2017). Pengaruh Pengawasan, kepemimpinan dan Kompensasi terhadap Kinerja Pegawai pada Badan Pengelola Keuangan dan Barang Milik Daerah Kabupaten Minahasa Utara. Jurnal EMBA, 5, 1921-1928

Mulyadi, D., \& Syafitri, A. 2015. Pengaruh Kepemimpinan dan Motivasi Kerja Terhadap Kinerja Karyawan di Bank BJB Syariah Cabang Bogor. Jurnal Ilmiah Binaniaga, 11(2)

Salusu, J. (2008). Pengambilan Keputusan Stratejik. Grasindo

Wibowo, W. 2016. Kepemimpinan (Pemahaman Dasar, Pandangan Konvensional, Gagasan Kontemporer). Cetakan Pertama. Jakarta: PT Raja Grafindo Persada 